\title{
Analysis of socio-economic indicators in the context of the regional development of Eastern Croatia
}

\author{
JELENA LONČAR ${ }^{1}$ and VeNI MARINKOVIĆ ${ }^{2}$
}

\begin{abstract}
The main goal of this paper is to analyse socio-demographic processes in Eastern Croatia. We focus especially on the structure of particular economic activities as well as population, which should be the basis of regional development. We have used several demographic and economic indicators to determine the changes that have taken place in the region. Trends in population change in the last decades, the share of industrial and agricultural workers in legal entities, the share of employed and unemployed persons in cities and municipalities, as well as the inactive population in five Eastern Croatian counties are examined. Also, agricultural indicators have been analysed, as this is one of the most important economic activities in this area. Thereby, an overview of the main trends in regional development of this area has been given, although some of the data were unavailable at the local level. Altogether, the authors have analysed 126 local units (22 cities and 104 municipalities) within five counties of the Eastern Croatian region.
\end{abstract}

Keywords: population change, regional development, economic indicators, Eastern Croatia

\section{Introduction}

The region of Eastern Croatia belongs to the underdeveloped group of regions according to the index of development (Ministartsvo regionalnog ... 2010). For this reason, the implementation of regional development policies has great significance.

Regional development is a broad term but it can also be seen as a general effort to reduce regional disparities by supporting employment and wealth-generating economic activities in such regions. In the past, regional development policy tended to try to achieve these objectives by means of large-scale infrastructural development and attracting inward investment. However, previous policies have failed to reduce regional disparities significantly and have not been able to help individual lagging regions to catch up, despite the allocation of significant public funding.
The result has been under-used economic potential and a weakened social cohesion, which is noticeable in the area today (www. oecd.org).

According to Hansen, Higgins and Savoie (1990) regional development policy usually implies all deliberate activities that the government implements with the goal of changing spatial distribution of economic and social phenomena like population, income, government incomes, manufacturing of different goods and services, transportation infrastructure, social infrastructure and political power (HANSEN, N. et al. 1990).

Also, it can be said that regional economic development can be seen as both a product and a process. It is a product of economic development as well as a process, for example in the case of industry support, infrastructure, the labour force and market development (Stimson, R.J. et al. 2006). Hence,

\footnotetext{
${ }^{1}$ Department of Geography, Faculty of Science, University of Zagreb, CR-10 000 Zagreb, Phone: + 0038514895 426. E-mail: jloncar@geog.pmf.hr

${ }^{2}$ Project assistant. University of Zagreb. E-mail: marinkovic.veni@yahoo.com
} 
cities, towns, counties and all local entities in the global economy have the challenge and opportunity of crafting their own economic destinies (Blakely, E. and Leigh, N.G. 2009).

In the Republic of Croatia, the process of establishment of a regional development concept can be traced back to its occurrence in Yugoslavia after World War II. through the changes of fundamental principles and approaches to regional development policy that took place in the period of Croatian independence and at the beginning of the European integration process. Based on the characteristics of regional development policies during each period, major deficiencies and consequences for today's structural problems can be identified.

Also, the comparison of Eastern Croatian indicators (consisting of the Slavonian and Baranjan regions) with indicators from some other neighboring regions, such as northeastern Bosnia and Herzegovina or Voivodina, would be interesting because they have similar characteristics, but such an analysis would be very difficult to achieve.

In the first place, since Bosnia and Herzegovina has complex administrative divisions it is impossible to attain the data that would be comparable with those in other countries. One possibility is to take the data for the whole Republika Srpska (the northeastern part of Republika Srpska borders with Slavonia and Baranja) and for the District of Brčko, and compare it with Eastern Croatian cities and municipalities. But in this case, the area does not have similar characteristics and would not be comparable. Also, the land utilisation data in the region of Voivodina (Serbia) are not from the same year as those used in this paper, which means that they are incomparable with the data for Eastern Croatia.

\section{Theoretical and methodological framework}

The problems of regional development and regional policy are two of the most impor- tant issues in Croatia today. They are part of governmental strategies for economic growth and recovery, but they are also the focus of scientists of different affiliations. Policy makers should be able to view economic and social realities through the lens of the correct geographic scale to identify appropriate policy packages (OECD 2014).

The authors will try to emphasise the importance of strategies and development plans in the context of regional development as identifying and promoting connections between economic, environmental and social goals, which should be beyond administrative boundaries (OECD 2014). Also, as data for Croatia as a whole is usually analysed in most scientific papers, authors consider that detailed analysis at the level of regions, and especially at the level of cities and municipalities, is necessary to fully understand the economic-geographic processes that characterise this area. Accordingly, we try to analyse demographic and economic problems at the local level, as they are more obvious than those at the county or state level.

In an attempt to establish to what extent changes in population and economic-geographic conditions have influenced the region of Eastern Croatia, we have established three hypotheses:

1 . The contemporary characteristics of demographic structures and trends are considered as one of the most important limiting factors of regional development in the region of Eastern Croatia.

2. There are significant demographic and economic structural differences between the local administrative units of Eastern Croatia, among which larger cities stand out especially as the cores, and smaller, demographically and economically weaker municipalities represent the rural periphery of this region.

3. The advantages of Eastern Croatia for stronger regional development have not been fully utilised. This especially refers to agriculture as one of the most important traditional and contemporary activities, primarily due to the favourable natural conditions in this area. 
Analysing official data from the Croatian Bureau of Statistics, we try to gain insights into the main features of demographic and economic trends in the area of Eastern Croatia through:

- The characteristics of Eastern Croatian population dynamics and structures, analysed through general population trend from 1953 to 2011 on the regional level, the index of population changes in the period of 1953-2011 at the local level and the index of ageing in 2011, in order to indicate the main demographic trends in this area.

- The number and share of employed persons in industry in legal entities at the local level.

- The percentage of (un)employed persons at the local level.

- The inactive population in the counties.

\section{Regional development policies in Croatia}

The attempt to establish a regional development policy at the beginning of Croatian independence was based on determining the areas with a preferred position within the state. In the 1990s, Croatia did not have a coherent regional developmental strategy, concept or policy. The territory of 20 counties, 268 cities and municipalities (49\% of the total number of local units) was specified by 4 acts of parliament as areas of special state care. These acts were: the law on special areas under government protection (NN $44 / 96)$, the law on hilly-mountainous areas (NN 12/02), the law on islands (NN 34/99) and the law on the reconstruction and development of the City of Vukovar (NN 44/01) (StaRc, N. and RAšıć, V. 2003). However, the effects of the above laws were not at the expected level, as it has been indicated by the contemporary economic and social trends. The first significant document on the issue of regional development in Croatia was The concept of the regional economic development of Croatia, published by the Economic Institute on the initiative of the Ministry of Economy in 1999 (ČavraK, V. 2002).
The awareness of the importance of regional development in overall Croatian development was increasingly strengthened at the beginning of the European integration process in 2001. Croatia has further increased activities in the field of regional development by adopting new legislature and strategic documents and also by establishing new institutions. Accepting the concept of European regional policy, which enabled the use of pre-accession funds intended for regional development projects, a special institution was established in 2008 that should participate in achieving a more balanced regional development. It was based on the sustainable management of natural resources. Also, the Agency for Regional Development was established in the same year to implement regional development programs and projects.

Although in terms of regional development, Croatia has been conceptually and institutionally moved away from its initial phase, the expected impact is still lacking. Many analyses indicate contemporary divergent trends in the concentration of population and the economy, which is the casein the Eastern Croatian region as well.

\section{Means of regional development}

Main means of regional development include the adopted legal acts and the development strategic documents that prescribe and define the objectives and measures of regional development policy. The basis of regional development policy is defined by the Regional Development Law (NN 153/09) ${ }^{3}$. It determines the goals and principles of regional development management in Croatia. It prescribes necessary planning documents, appoints competent state entities and classifies the development stages of different spatial units. Also, the law prescribes the adoption of regional planning documents at the national level (Regional Development Strategy of the

\footnotetext{
${ }^{3}$ At the end of 2013, a draft of the Regional Development Law was introduced to the public as an update to the former Regional Development Law enacted in 2009.
} 
Republic of Croatia, 2011-2013) and regional level (county development strategies). It is also in line with practice and requirements that derive from Croatian pre-accession obligations towards the EU. This law poses a few very important facts:

1. Induct the practice of partnership as the main method of working to shape regional development policy and as the basic institutional structure that will enable participatory work methods such as this.

2. Introduce a unique model of evaluation and classification of regional and local units according to degrees of development and a unique system of criteria for the selection of areas with developmental difficulties.

3. Define the main planning documentation that programmes regional development through conciliating and unifying development in the entire Croatian development policy.

4. It clearly defines the role and responsibility of regional development policy host at the state level.

5. It clearly defines the role and responsibility of regional development policy host in conception and leadership.

6. It institutionalises the principles and management of regional development policy and introduces unique terminology.

7. For more efficient planning and monitoring of the functionality of regional policy, it identifies the central electronic base of development projects.

In the Strategy of Regional Development (2010), regional development policy is defined as the entirely adjusted agglomerate of goals, priorities, measures and activities aimed at strengthening the competition of regional and local units according to principles of sustainable development and decreasing regional inequalities according to the degree of development. The Regional Development Policy in Croatia is defined by specific laws and it is mostly focused on the local level.

Also, part of the non-specific assistance is included in the law on government support for agriculture and fishery (Law on Government support for Agriculture and
Rural Development); the law on the promotion of investment; and the law on the promotion of development for small entrepreneurship. These three laws are not only for areas facing difficulties in development, but also for the Republic of Croatia in general.

An important tool for classifying the heterogeneity and regional differences of spatial units in Croatia is the development index. It classifies administrative units in comparison with the national average using income per capita, the unemployment rate, citizens' source income in different counties and/or municipalities, population trends and educational levels as relevant criteria. However, new tools are needed to understand what influences the places where people live and work (OECD 2014).

\section{Croatian NUTS II classification as EU regional development instrument}

The Bureau of Statistics determined Croatia's NUTS classification in 2002 with EUROSTAT's help and recommendations. All of Croatia is classified as one NUTS I region, while NUTS III regions are counties and NUTS V entities are cities or municipalities. However, problems occurred during the determination of NUTS II regions, because the county level (NUTS III) was too small and the level of Croatia as a whole (NUTS I) was considered to be too big. On the other hand, most European regions are monitored and analysed at the NUTS II level. Regional development and the use of the EU structural funds are expected at this level. It is also a basic framework for the implementation of regional policy and the standard level of data availability.

Through a new statistical classification in 2012 by the Ministry of Regional Development and EU funding bodies, Croatia was divided into two NUTS II regions: Continental and Adriatic Croatia. Continental Croatia consists of 13 counties (Zagreb, Međimurje, Varaždin, Krapina-Zagorje, Bjelovar-Bilogora Koprivnica-Križevci, Virovitica-Podravina, 
Osijek-Baranja, Požega-Slavonija, Slavonski Brod-Posavina, Vukovar-Sirmium, Karlovac, and Sisak-Moslavina counties) and the City of Zagreb. It has 64.1 percent of the $27 \mathrm{EU}$ countries' GDP. Adriatic Croatia consists of 7 counties (Lika-Senj, Primorje-Gorski Kotar, Istria, Zadar, Šibenik-Knin, Split-Dalmatia and Dubrovnik-Neretva counties), and has 62.1 percent of the 27 EU countries' GDP.

This kind of statistical division enables the use of resources from the Structural Funds with the highest benefits to all Croatian regions. Also, it facilitates the implementation of development projects following the same rules in the entire territory of the Republic of Croatia (Ministry of Regional Development and EU funds). Observed in terms of European NUTS II classification according to the division from 2012, Eastern Croatia belongs to the statistical region of Continental Croatia, which has about 62 percent of the 27 EU countries' GDP. However, it is generally known that Eastern Croatian counties have a significantly lower average GDP because other, more developed counties of Central Croatia also belong to this NUTS II region (City of Zagreb, Zagreb County etc.), which raise the average.

\section{Demographic characteristics as a factor of economic development}

As population is the most important factor of regional development planning, it is necessary to consider recent demographic processes and structures in terms of identifying the main problems and to evaluate population resources in the Eastern Croatian region. Large differences between particular parts of Eastern Croatia are expressed in terms of population, especially between urban and rural areas, mostly as a result of 'de-agriculturisation', ruralisation and industrialisation after World War II.

Today, according to the 2011 Census, there are about 806,000 people living in the five counties in the Eastern Croatian region. The Eastern Croatian region's population trend since World War II has indicated two different stages of population development. The first is characterised by the increase in the total population of Eastern Croatia until 1991 and the Homeland War. Since then a period of depopulation has taken place. However, the stagnation or decline in population was recorded in some counties in the 1981 Census (Virovitica Podravina and Požega-Slavonia counties), indicating that the process of shrinkage had already started.

The entire region of Eastern Croatia, as well as all its counties, has recorded a significant loss of population in the last three decades, the most intensive periods being the intercensual periods of 1991-2001 and 2001-2011, during which the region of Eastern Croatia lost about 170,000 people. In the last intercensual period the population decline of Eastern Croatia were about 85,000 people in total, which is about 9.6 percent of the total population of Eastern Croatia in 2001. At the same time, natural decline, together with the increased emigration of working and reproductive age groups, has led to a noticeable deterioration in the age-sex population structure of Eastern Croatia (Wertheimer, A. and Žıvic, D. 2003 (Figure 1).

Negative changes in the population in the last three decades has resulted in a decline of

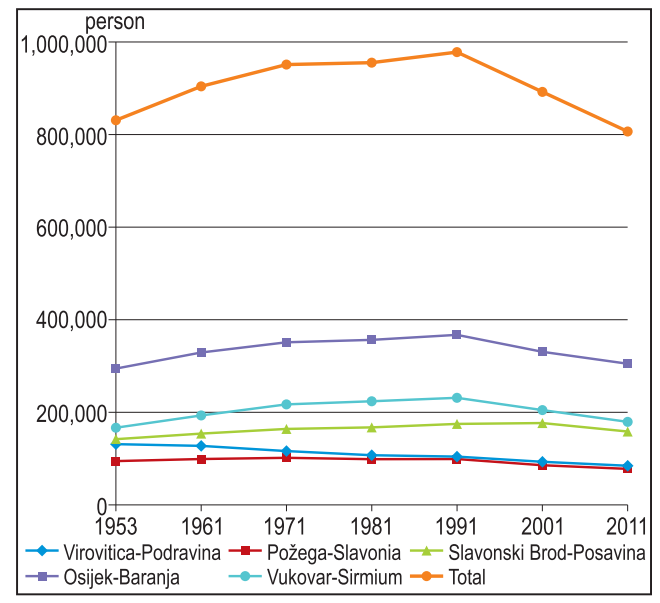

Fig. 1. Population of Eastern Croatia 1953-2011, by counties. Source: 1857-2001 Censes, 2011 Census, www.dzs.hr 
more than 170,000 inhabitants in the region of Eastern Croatia (in the 2011 Census only Dragalić in Slavonski Brod-Posavina county had minimal population growth in relation to the 2001 Census). The main causes of such an unfavourable state are the consequences of the decline in birth rates, increased mortality rates, emigration, adverse economic conditions and the consequences of war in the region of Eastern Croatia. Peripheral rural areas have suffered especially as the process of "village senilisation" has been emphasised with the emigration of younger age groups (CifRIĆ, I. 2003). In this way, the development potential of Eastern Croatia has been significantly reduced.

The demographic changes of the Eastern Croatian local units are presented by the index of changes in the number of residents in the period of 1953-2011 in order to show the intensity and spatial distribution of depopulated areas, as well as the areas of population increase within the local units. The index values of less than 100 indicate depopulated areas in the period of 1953-2011 (Figure 2). Mainly, these are rural municipalities that are more distant from the urban centres in Eastern Croatia, mostly in the western and northern parts of Slavonia, especially in Podravina, Posavina and the Western Slavonian micro-regions.

The process of depopulation has been the most intensive in these areas, which reduces the possibilities of local and regional development. It is especially important to emphasise that 72 percent of all local government units in this macro-region have recorded a population decline over this period. Among them, more than one-third has recorded a decrease of 50 percent or more. For example, in 2011 the municipality of Čađavica in the micro-region of Podravina had only 27 percent of its 1953 population. On the other hand, index values over 100 represent areas with population increases in the period of 1953-2011.

Their spatial distribution indicates the population increase bigger urban areas or macroregional and regional centres, such as the City of Osijek (163.5\%); Slavonski Brod (255.8\%); Virovitica (140.7\%); Požega (169.9\%); Đakovo (150.9\%); and Vinkovci (169.5\%). Also, areas and municipalities in their surroundings recorded a population increase, for example, in the Slavonski Brod region there were increases in the municipalities of Sibinj (114.8\%) and Brodski Stupnik (110.1\%); in the Osijek region in the municipalities of Darda $(152.7 \%)$, Cepin (155.5\%) and Antunovac (106.8\%); and in the Vinkovci region in the municipalities of Ivankovo (129.6\%), Nuštar (140.6\%) and Andrijaševci (130.9\%).

These data indicate the process of population concentration in urban centres, mostly in the large macro-region (Osijek) and other regional and county centres (Slavonski Brod, Požega, Vukovar, Vinkovci and Virovitica) in relation to the remaining rural areas of the region. Only 35 of all local units recorded a population increase in this period and among those three had a doubling of the number of residents while others had less significant increases. The macro-region of Osijek recorded an overall increase of 60 percent compared to 1953, which does not belong to the largest increase compared to other urban areas, due to the advanced suburbanisation process.

Another indicator of demographic characteristics and the region's potential is the index of ageing. It represents the ratio of the age group of 0-19 (youth) and over 60-yearolds (senior) (Figure 3).

Generally, a population is considered to be elderly if the index of ageing is over 40 (Nejašmić, I. 2006). The ageing index indicates that the population of Eastern Croatia is in general very old. It is an especially remarkable phenomenon if considered at the local level. First of all, it is important to emphasise that no one of the Eastern Croatian local units had an index of ageing less than 40 in 2011. The lowest values or the most favourable ratio of youth to elderly was found in urban areas and the municipalities in their surroundings (with an index of ageing less than 80). At the same time, the oldest population was to be found in rural municipalities. In particular, the municipalities and one city 


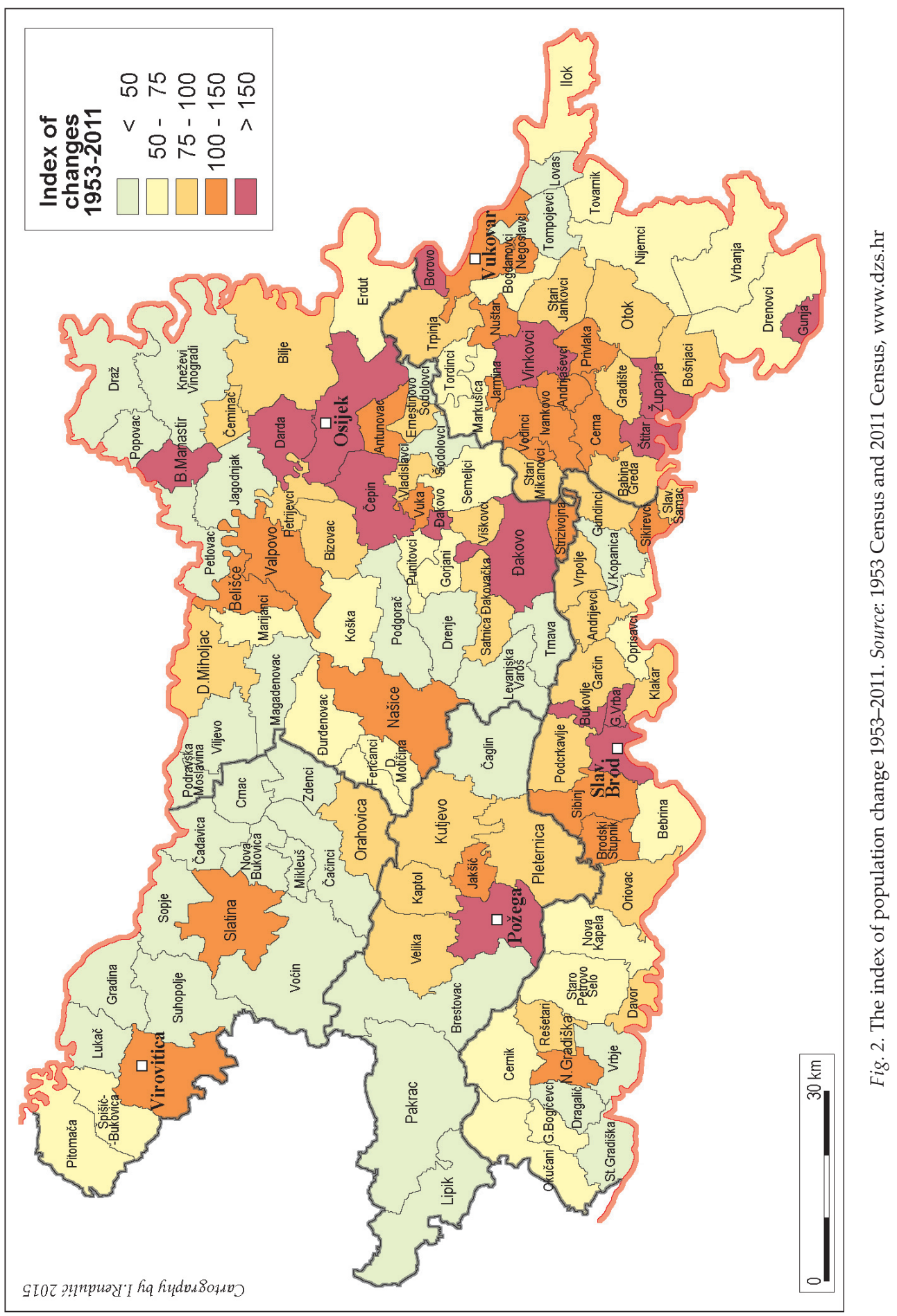




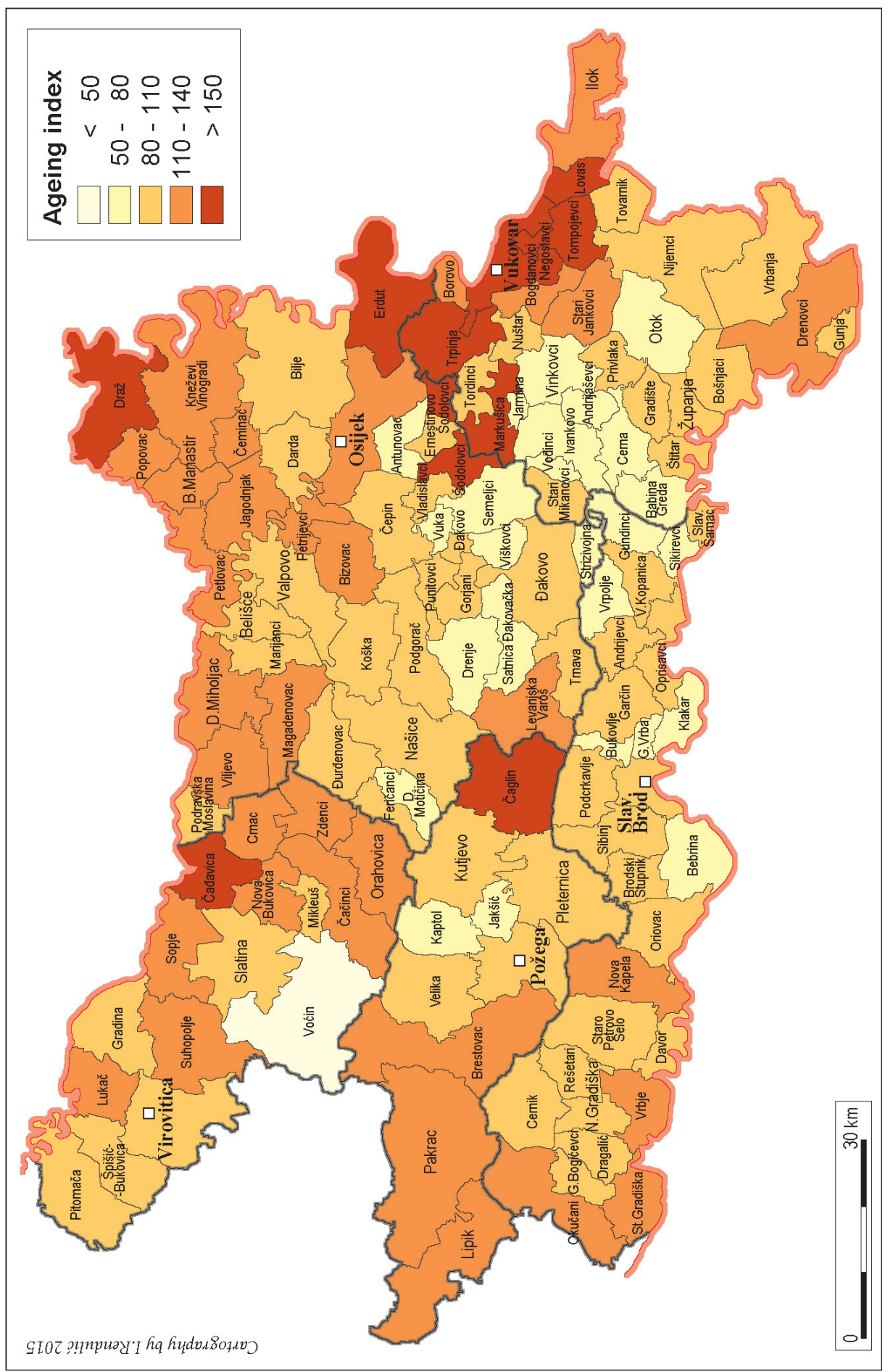

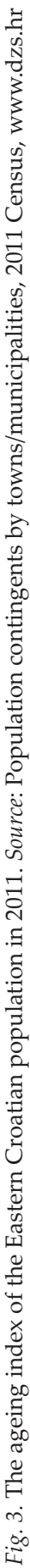


in Eastern Slavonia (Vukovar, Erdut, Ilok, Lovas, Negoslavci, etc.) had the highest values in the index of ageing, which is a consequence of the war and youth emigration .

These indicators show the Eastern Croatian region's demographic potential and problems. The most important demographic indicators reflect the processes of depopulation, regional population concentration and the unfavourable age structure of the population. At the same time, the spatial distribution of these unfavourable processes indicates that bigger urban centres and the municipalities in their surroundings record better demographic profile and structures in comparison with remote rural municipalities.

Migration is considered to be an important key in solving the puzzle of providing a healthy foundation for future economic growth. For those areas that are increasingly was held in Croatia in 2003, 27 percent of all Croatian agricultural households were in the region of Eastern Croatia, as well as 43 percent of all business entities. Unfortunately, the current situation in the agricultural sector of Eastern Croatia is characterised by small farms, an aging workforce and a small and uncertain market.

The involvement in the global agricultural market is still too much to expect at this level of agricultural development in Eastern Croatia. In most of the counties in Croatia, including the counties of Eastern Croatia, most of the utilised agricultural land is up to 5 ha (in some counties up to 50 percent of all utilised land). The strategy for enlargement of the parcels should be re-parcelling and land management. In this way, the agricultural sector should be able to grow and have bigger production and export (Table 1).

Table 1. Basic agricultural indicators of utilised agricultural land in Eastern Croatia by counties, 2003

\begin{tabular}{l|c|c|c|c|c}
\hline \multirow{2}{*}{ County } & \multicolumn{2}{|c|}{ Number of } & \multicolumn{3}{c}{ Utilised agricultural land, hectares } \\
\cline { 2 - 5 } & households & $\begin{array}{c}\text { business } \\
\text { entities }\end{array}$ & total & $\begin{array}{c}\text { in agricultural } \\
\text { households }\end{array}$ & $\begin{array}{c}\text { in land business } \\
\text { entities }\end{array}$ \\
\hline Virovitica-Podravina & 19,062 & 78 & 83,752 & 58,862 & 24,890 \\
Požega-Slavonia & 13,521 & 37 & 42,548 & 31,675 & 10,873 \\
Slavonski Brod-Posavina & 20,704 & 109 & 62,316 & 47,377 & 14,939 \\
Osijek-Baranja & 41,103 & 235 & 184,094 & 95,987 & 88,107 \\
Vukovar-Sirmium & 26,316 & 130 & 121,078 & 84,821 & 36,257 \\
\hline
\end{tabular}

Source: Agricultural Census, 2003 (www.dzs.hr)

confronted with population aging, attracting the flow of young people represents the only alternative in the short and medium term (MAZILESCU, R. 2012). The biggest problem in this region is the emigration of skilled labour because productive workers move to urban areas that pay higher real wages while the sending/source region becomes less specialised and less productive (EDwards, M. 2007).

\section{Economic-geographic indicators of development}

As agriculture and industry, especially the food industry, are two traditional economic activities in Eastern Croatia, they will be analysed in the next section of this paper. In the period of the last agricultural census that
If the agricultural structure of Eastern Croatian households and business entities are analysed, it is obvious that the number of agricultural households is much larger than the number of business entities. The same applies in the case of utilised agricultural land that is in the hands of households. Data show that utilised agricultural land that is used by agricultural households is almost twice as big as the utilised agricultural land used by business entities. This shows that an attempt to make bigger businesses in the agriculture sector in Croatia is still economically risky. Croatian farms are among the smallest in the EU.

Besides that, our data show that the number of agricultural workers in most cities and municipalities is below 10 percent, while only municipalities farther from bigger 
cities or regional centres have a population made up of over 30 per cent of agricultural workers. Some of them (Vrbanja, for example) are more focused on the forestry sector (Figure 4). This result is significant if we take into account that traditionally this is an agricultural area with all the preconditions for the further development of the agricultural sector (ecological cultivation, for example). However, years of neglect and lack of investment that would have improved knowledge in agricultural business, as well as a lack of investment in new technologies and the lack of local communities' capacity to get more resources from EU funds, have had the result that Croatia imports a significant part of its food products from abroad

As Croatia became member of the EU there have been many opportunities for Eastern Croatia's agricultural sector using EU funds. "The agricultural sector of rural development satisfies an economic way of reasoning which turns out to be insufficient to enable rural areas to apprehend the new issues of territorial cohesion. In order to contribute to the Lisbon and Gothenburg objectives, rural development strategies should focus on innovation and the transfer of knowledge and good practices" (Zorzoliu, R. 2012).

In general, rural areas should play a more significant part in regional and economic development if the further concentration of population and economic activities in Eastern Croatia are wanted to be avoided. The contemporary understanding of rural development involves a comprehensive development with the participation of the community itself, or the process by which institutions and people from the community are mobilised in order to create, strengthen and stabilise activities using the resources of the area in the best possible way to achieve stable economic and social development (GrefFe, X. 2005).

The modern local development policy is based on the OECD approaches and principles of: qualitative development, a differentiated and unique approach to each local area and the involvement of local stakeholders in the creation and implementation of their own development. The main characteristic of recent rural development policy is an effort to stop the developmental delay of rural areas by efficient use of all local resources. Directing rural development strives to increase the competitiveness of agriculture and forestry, improve the environment, landscape, and quality of life in rural areas and diversify the rural economy. The contemporary rural developmental policy is based on the LEADER approach, which means, "links between the actions in development of the European rural areas", which is also the method used to mobilise the potential of rural communities. This also includes:

1. Sustainable rural development based on the conservation and balancing of environmental, social and economic capital;

2. Approach based on local characteristics, potential, uniqueness and distinctiveness;

3. Bottom-up approach, which means that local stakeholders are involved in taking decisions;

4. Establishment of local partnerships (local action groups) composed of public, civil and economic sectors that seek to identify and implement local development strategy;

5. Innovations to represent traditional values in a new and competitive manner;

6. Integrated, multi-sectoral approach involves horizontal, cross-sectorial as well as vertical connectivity, linking local, regional and national institutions in order to achieve sustainable rural development;

7. Networking and connectivity, learning from best practices, exchange of knowledge and experience;

8. Cooperation representing a further step of networking towards the development and implementation of individual projects of two or more LAGs within a country or region.

Rural development and the LEADER approach are relatively new concepts in Croatia, dating back to the early implementation of the European model of rural development and the pre-accession IPARD programme in which it was a key instrument. In accordance with it, in 2008 the Strategy of Rural Development 2008-2012 was adopted in Croatia, with the main objectives 


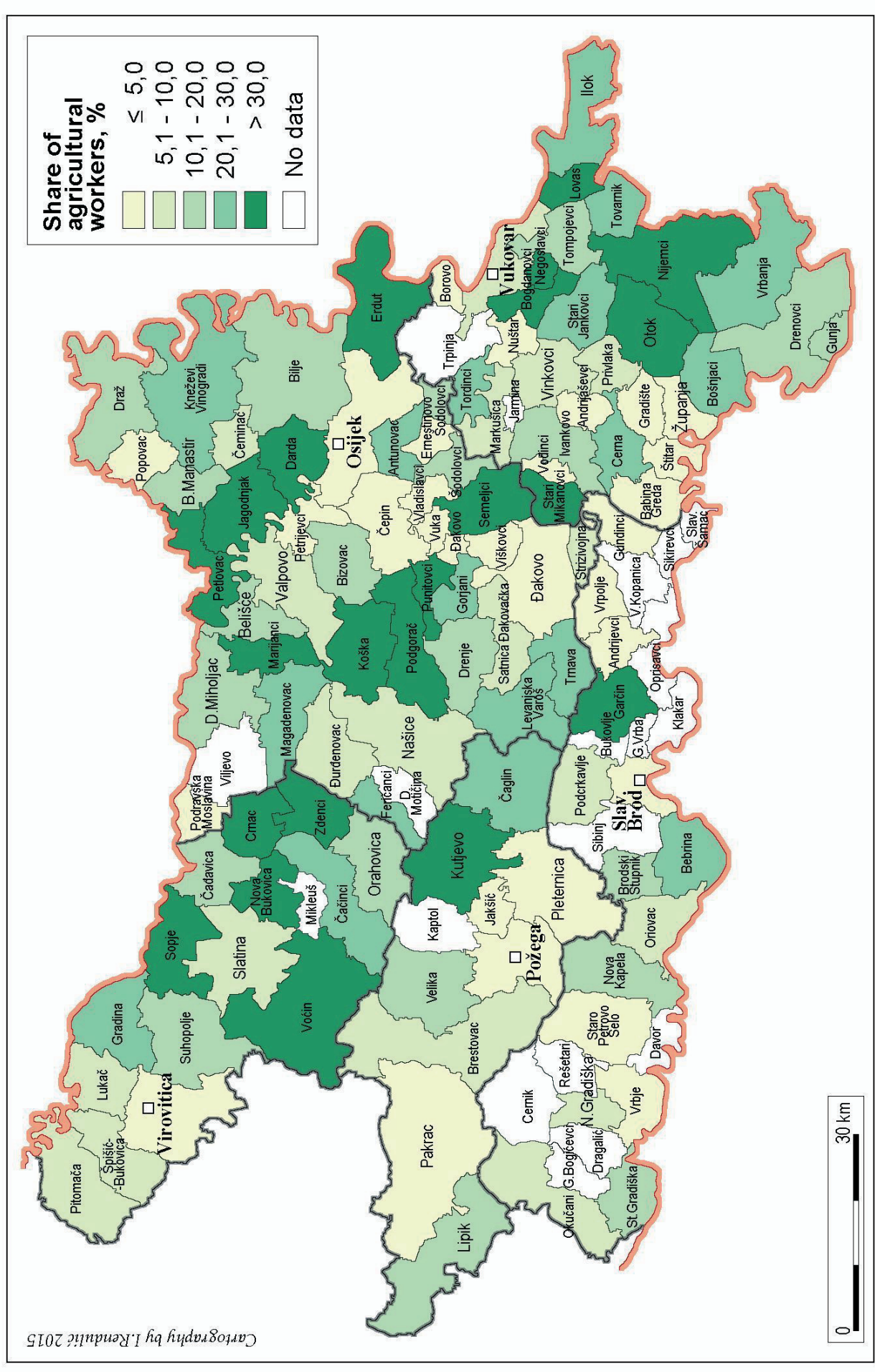

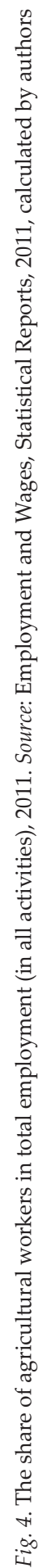


and measures of developing agriculture and rural areas. Through the EU accession, Croatia opened up the possibility of using the European Agricultural Fund for Rural Development (EARDF), financed by the Common Agricultural Policy (CAP), which contributes to achieving the objectives of the Europe 2020 strategy promoting sustainable rural development throughout the European Union.

Nowadays, Croatia is implementing the Rural Development Programme 2014-2020 with defined measures that outline the effective usage of resources from the fund.

When analysing industry, it is necessary to say that in this region it has traditionally been based largely on agricultural production, but "unfortunately", the percentage of agricultural products that are finalised in this region is not known. However, empirically it may be concluded that the insufficient degree of completion, which affects the levels of employment in the region, affects the low level of new investment and economic growth" (BABAN, L.J. and Ivic, K. 2003).

The most severe decline of industry in this area happened after 1990 when the war caused big damages and the destruction of factories that then stopped operating and were closed. Also, badly managed privatisation and the new rules that capitalism brought found Croatian industry unprepared. Under these conditions, the loss of old markets and the lack of new ones almost caused the collapse of industry in Eastern Croatia. In the Republic of Croatia, the number of employed persons in industry decreased after the transition and privatisation almost threefold. New jobs in industry in the meantime (reindustrialisation) have not materialised.

From the data available, it is obvious that in Eastern Croatia only 5 cities/ municipalities have industrial employment of over 60 percent and their economy is mostly connected to the paper and petroleum industries (a refinery in Slavonski Brod). A slightly better situation can be found in the area of Western Slavonia with the city of Požega as its centre, while in Eastern Slavonia and Baranja, mostly in cities like Donji Miholjac, Valpovo, Beli Manastir and Županja, industrial employment is above average (more than 30 percent). Eastern Croatia in general has an average industrial employment rate of around 22 percent. Today, industry is still the most significant economic activity in this area if the number of employees in industry and other economic sectors are compared (Table 2).

The main characteristic of the business life in Croatia is the decline of the working poplation, which is a result of negative demographic development, emigration and an ageing of workforce. The necessary policies that should be implemented should take into consideration the following goals: an increase of the active population, an increase of the employment rate, as well as an increase of workforce mobility, because the labour market is a major factor in determining the economic growth of an area (Edwards, M. 2007). This is why communities must continuously invest in assuring a highly skilled workforce (BLAKELY, E. and Leigh, N.G. 2009) (Figure 5).

Analysing the statistics for Croatia as a whole, the number of registered business entities increased by 9.56 percent during the period of 2008-2012, from 263,760 registered business entities to 288,972 . The increase occurred in all sectors except for public defence, compulsory social security, wholesale and retail trade. The largest number of new businesses during the period 2008 to 2012 have been registered in wholesale and retail trade, followed by construction, manufacturing and professional, scientific and technical activities. Unlike the 9.56 percent increase in the number of registered legal entities, the number of active legal entities in the observed period increased only by 1.69 percent, or by 2,224 legal entities (Industrial Strategy for Republic Croatia, 2014).

Also, for Croatia as a whole, the long-term unemployment rate of 18.9 percent (in 2012) has been an unsolvable problem for several years. The main problems that the government also tries to cope with are: the low share of active population, structural inconsistency of supply and demand in professional occupa- 


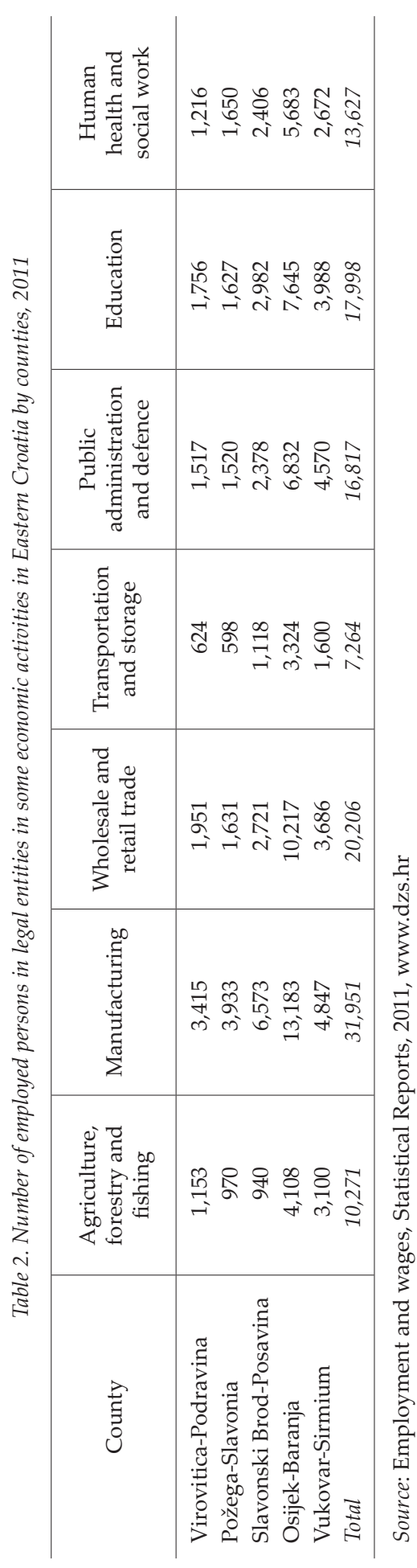

tions, the low number of flexible and adaptable companies and the low utilisation of human potential and resources (Industrial Strategy for Republic Croatia, 2014) (Figure 6).

The problem of unemployment persists because the number of unemployed is almost permanently higher than the demand. Therefore, employers behave as if staff were always available, as reflected in the very low level of investment in employee education. However, the existence of a structural mismatch has been confirmed by Croatian Employment Service and research results also indicate a lack of specific personnel, the existence of occupations and the lack of certain skills among those who apply for the job. The clustering of the most capable, highly educated people in the field of services could be a limiting factor for reindustrialisation based on new materials and technologies in terms of increased competition.

The planning of necessary resources by using stimulation to select the required interests, determining quotas and adapting educational program needs with adequate financial support can lead to improvements in the structure of knowledge and skills that are necessary for development (Industrial Strategy Republic of Croatia, 2014) (Figure 7).

When analysing the active and inactive populations of Eastern Croatia at the county level, it becomes clear that in every county the share of inactive population is over 50 percent and in some cases close to 60 percent (Požega-Slavonia county, for example). The biggest number/share of the inactive population involves pupils and students as well as retired people. These indicators show a very small worker pool that can't be the base for economic and regional development and prosperity, especially in periods of economic stagnation or crisis, and it will also influence the decline of GDP per capita.

If GDP data for the year of 2005 on the NUTS 2 level is compared between the EU and Croatia, the regional GDP in Eastern Croatia according to purchasing power parity is only at 34.5 percent of the EU average (while, for example, the North-western region of Croatia 


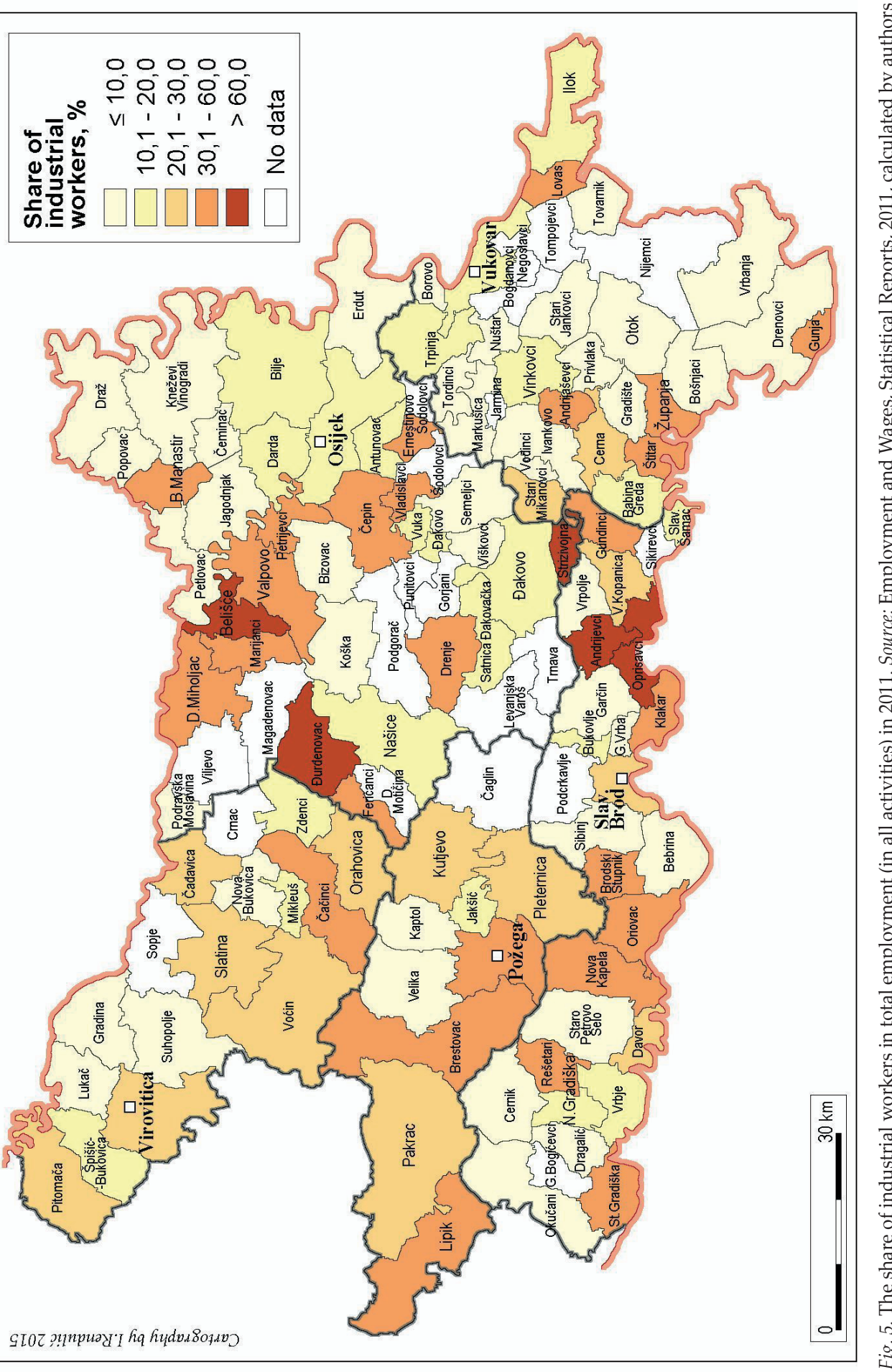




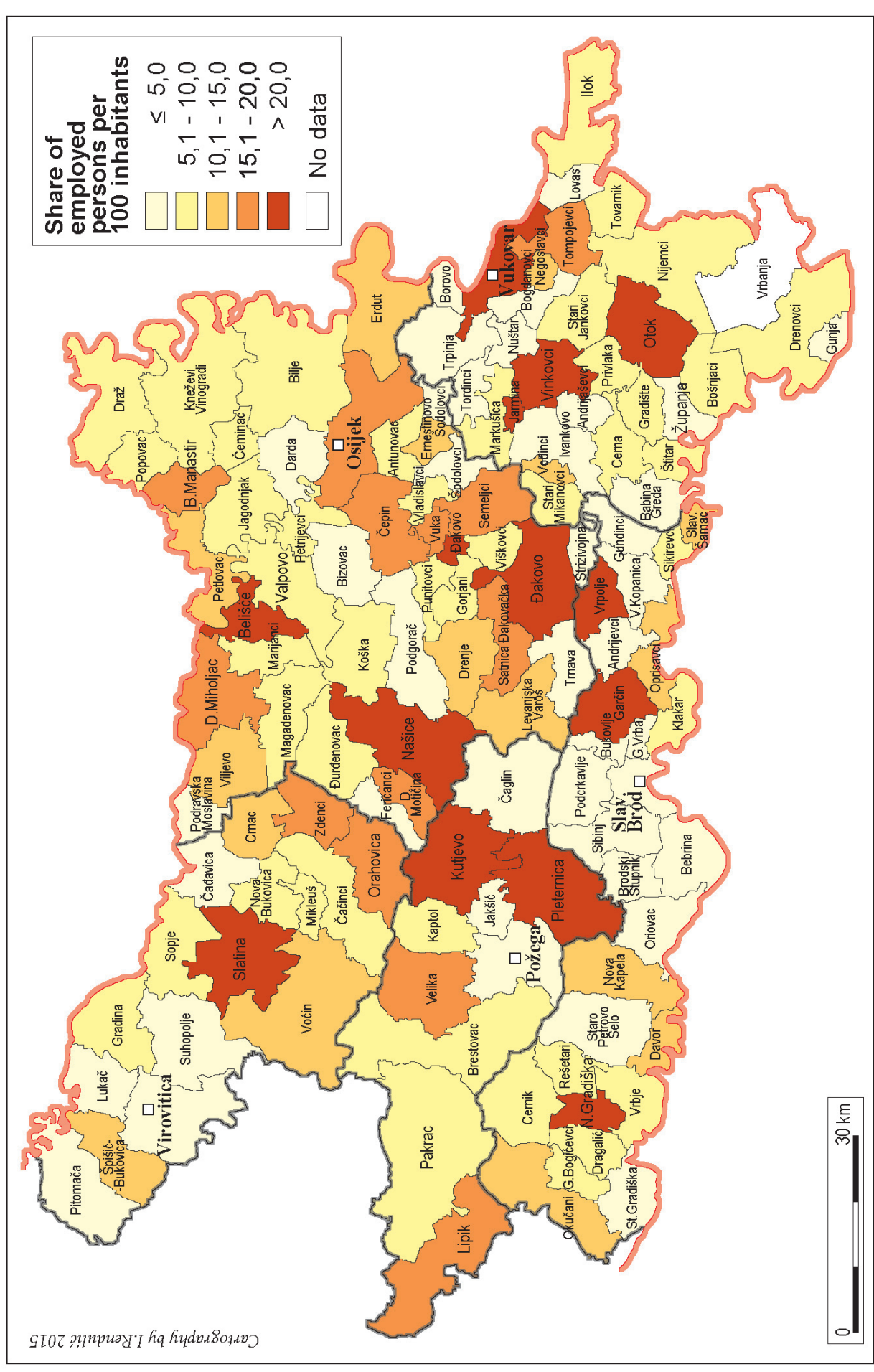

D) 


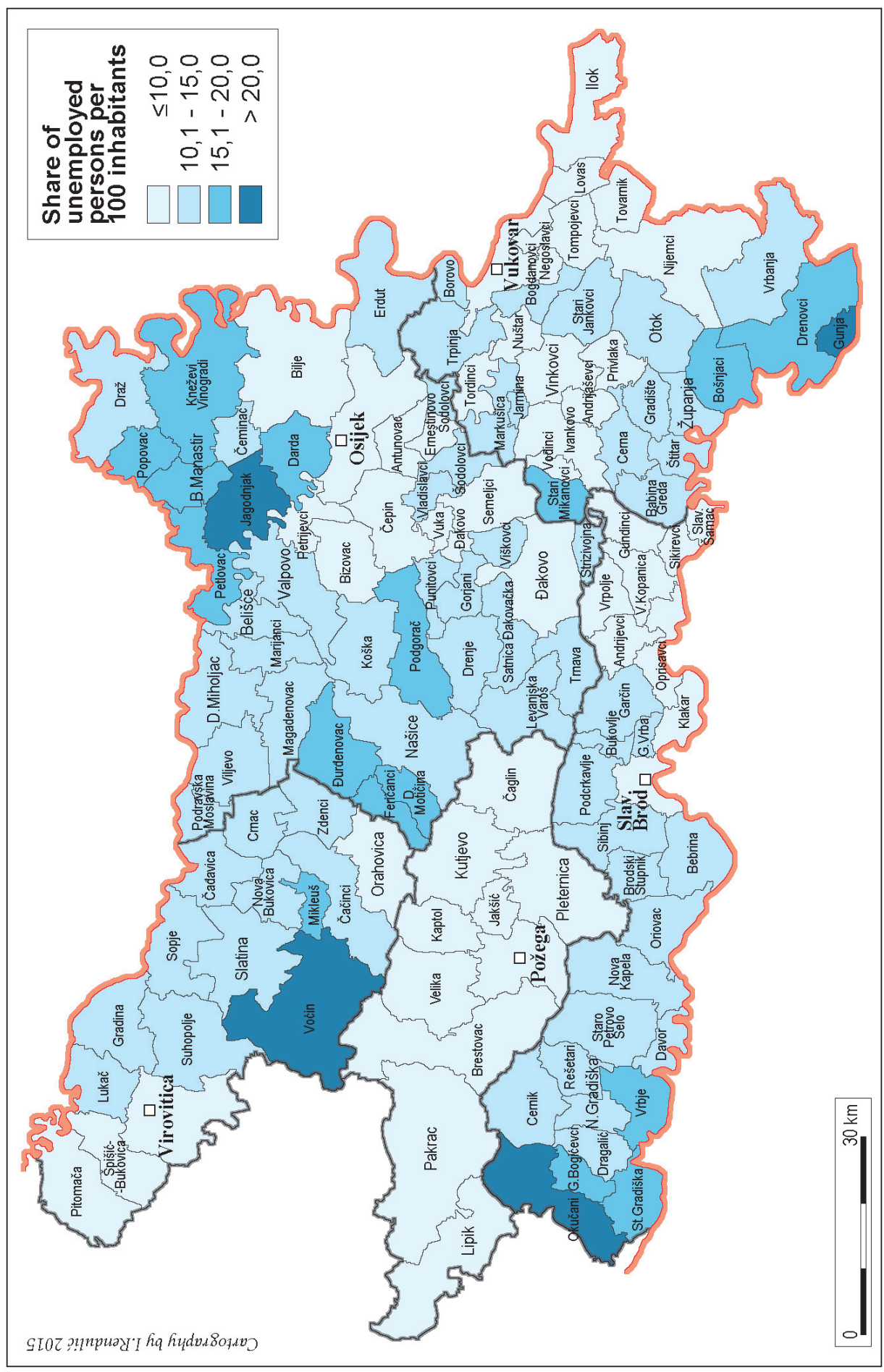


is at 64.3 percent of the EU average and the Adriatic region is at 47.6 percent of the EU average). Differences in wealth between these three regions can be linked back to the main economic structure, i.e. the share of certain sectors compared to national average. Eastern Croatia is economically very homogeneous, while the other two regions have more heterogeneous economical structures. Regions with a narrow economic base are more sensitive to all economic crises and less competitive in comparison with regions that have a broader economic base (Strategy for Regional Development). If we also take into consideration demographic structures in Eastern Croatia, the number of active members in the population declines further (Table 3). opment of these activities and investment in new technologies and research will not be possible. Both of these sectors have been in economic crisis for decades. That is why specialised geographical production systems should be developed to serve as a basis for the food industry and the agro-food sector in general. A big part of this production could be used in the tourism sector to a much greater extent than it is now.

In this context, authors can conclude that the first hypothesis is confirmed. As the population is the most important factor of regional and local planning and development, the unfavourable demographic dynamics and structural characteristics of Eastern Croatia reduce development po-

Table 3. Population of Eastern Croatia by current activity status, 2011

\begin{tabular}{|c|c|c|c|c|c|c|c|}
\hline \multirow{2}{*}{ County } & \multirow{2}{*}{$\begin{array}{l}\text { Population, } \\
\text { person }\end{array}$} & \multicolumn{2}{|c|}{ Employed } & \multicolumn{2}{|c|}{ Unemployed } & \multicolumn{2}{|c|}{$\begin{array}{l}\text { Economically } \\
\text { inactive }\end{array}$} \\
\hline & & person & $\%$ & person & $\%$ & person & $\%$ \\
\hline Virovitica-Podravina & 71,344 & 24,084 & 33.7 & 6,662 & 9.3 & 40,577 & 56.8 \\
\hline Požega-Slavonia & 64,892 & 21,948 & 33.8 & 5,727 & 8.8 & 37,194 & 57.3 \\
\hline Slavonski Brod-Posavina & 131,512 & 41,804 & 31.7 & 15,393 & 11.7 & 74,288 & 56.4 \\
\hline Osijek-Baranja & 258,226 & 95,300 & 36.9 & 26,363 & 10.2 & 136,505 & 52.8 \\
\hline Vukovar-Sirmium & 149,070 & 48,894 & 32.7 & 16,426 & 11.0 & 83,693 & 56.1 \\
\hline
\end{tabular}

Source: Population aged 15 and over by current activity status, age and sex, Census 2011, www.dzs.hr

\section{Conclusions}

Eastern Croatia is a region with numerous economic and development advantages in comparison to other Croatian regions. Unfortunately, there are also numerous disadvantages that have disabled the full use of resources and capacities in this area.

One of the biggest problems is depopulation and the lack of young and educated people who are usually the 'engine' of positive changes and the basis for social and economic development..

In terms of agriculture and industry, once the traditional sectors in the region of Eastern Croatia, without further financial help from the state and EU cohesion and structural funds, the further restructuring and devel- tential in this region, especially at the local level. The second hypothesis in this paper is not confirmed fully, as indicators show that the whole of Eastern Croatia has similar population and economic-geographic problems. However, at the local level, we have demonstrated that bigger urban centres and municipalities and their surroundings have a better developmental position in comparison with remote rural municipalities. The third hypothesis is confirmed, as population and economic potentials of Eastern Croatia for regional development are not used in a way that would increase regional prosperity and the development of this area.

Eastern Croatia's unique identity might become a significant resource and could be utilised for the further development of regional economy in agriculture, tourism or other economic activities. 


\section{REFERENCES}

BABAN, L.J. and Ivıć, K. 2003. Diversifikacija kao bitna strategija razvitka poljoprivrede i prehrambene industrije Istočne Hrvatske. In Razvojne perepektive ruralnog svijeta Slavonije i Baranje. Eds.: ŠтAмвUк, M. and Šundalić, A. Zagreb, Institut društvenih znanosti Ivo Pilar, 209-219.

Blakely, E. and Leigh, N.G. 2009. Planning Local Economic Development: Theory and Practice. Los Angeles, Sage Publications, $480 \mathrm{p}$.

ČAVRAK, V. 2002. Strategija i politika regionalnog razvoja Hrvatske. Ekonomija 3. 645-661.

Cifrić, I. 2003. Iskustva mješovite poljoprivrede: obiteljsko gospodarstvo u tranzicijskim promjenama i novim izazovima. In Razvojne perepektive ruralnog svijeta Slavonije i Baranje. Eds.: Šтамвик, M. and Šundalić, A. Zagreb, Institut društvenih znanosti Ivo Pilar, 129-143.

Edwards, M. 2007. Regional and urban economics and Economic development: Theory and Methods. New York, Auerbach Publications, $752 \mathrm{p}$.

GREFFE, X. 2005. The instrument of good governance. Local governance and the drivers of growth. Paris, OECD Publishing, 39-88.

Hansen, N., Higgins, B. and Savoie, D. 1990. Regional Policy in Changing World. New York, Springer Science and Business Media, $311 \mathrm{p}$.

Mazilescu, R. 2012. Patterns of demographic development. Procedia. Economics and Finance 3. 1075-1080.

Ministarstvo regionalnog razvoja, šumarstva i vodnog gospodarstva 2010. Strategija regionalnog razvoja Republike Hrvatske, 2011-2013. (Strategy of Regional development of Republic Croatia, 2011-2013) www. mrrfeu.hr

NejAšmić, I. 2006. Demogeografija. Stanovništvo u prostornim odnosima i procesima. Zagreb, Školska knjiga, $283 \mathrm{p}$.

OECD Regional Outlook 2014. Regions and Cities: Where Policies and People Meet. OECD Publishing, $291 \mathrm{p}$.

Starc, N. and Rašrć, I. 2003. Nevolje s regionalnom politikom. Privredna kretanja I ekonomska politika 95. 47-86.

Stimson R.J., Stough R.R. and Roberts B.H. 2006. Regional Economic Development: Analysis and Planning Strategy. Berlin-Heidelberg-New York, Springer, $452 \mathrm{p}$.
Wertheimer, A. and Živic, D. 2003. Demografske promjene u ruralnim područjima Slavonije i Baranje od 1953. do 2001. godine. In Razvojne perepektive ruralnog svijeta Slavonije i Baranje. Eds.: ŠтАмвUк, M. and Šundalić, A. Zagreb, Institut društvenih znanosti Ivo Pilar, 15-39.

Zorzoliu, R. 2012. Regional and sustainable development in Italy, Procedia. Social and Behavioral Sciences 58. 514-522.

Additional sources:

Croatian Bureau of Statistics 2011. Naselja i stanovništvo RH 1857-2001 (Census 1857-2001). cd, Zagreb, R. Hrvatska, www.dzs.hr

Croatian Bureau of Statistics 2011. Popis stanovništva 2011. Kontingenti stanovništva po gradovima $i$ općinama (Census 2011. Population contingents by Towns and Municipalities). Zagreb, R. Hrvatska, www.dzs.hr

Croatian Bureau of Statistics 2012. Robna razmjena RH s inozemstvom po županijama, gradovima $i$ općinama (Foreign trade in goods of the Republic of Croatia by counties, towns and municipalities). Priopćenje god. XLIX. Zagreb, R. Hrvatska, www.dzs.hr

Croatian Bureau of Statistics 2012. Zaposlenost i plaće (Employment and Wages, Statistical Reports), Zaposleni u pravnim osobama po županijama gradovima i općinama. Statistička izvješća. Zagreb, R. Hrvatska. www.dzs.hr

Croatian Bureau of Statistics. 2003. Popis poljoprivrede (Agricultural census). Zagreb, R. Hrvatska,. www. dzs.hr

Croatian Emloyment Sevice 2011. Mjesečni statistički bilten (Monthly Statistic Bulletin). www.hzz.hr

Minisarstvo regionalnog razvoja i fondova EU. www. mrrfeu.hr

Ministarstvo gospodarstva 2014. Industrijska strategija Republike Hrvatske 2014-2020 (Industrial strategy of Republic Croatia, 2014-2020). Zagreb, R.Hrvatska. www.mingo.hr

Ministarstvo gospodarstva RH. Industrial Strategy of Republic Croatia, 2014-2020.(www.mingo.hr)

Nacrt zakona o regionalnom razvoju 2013. http:// www.mrrfeu.hr/default.aspx?id=1674

OECD, Better policies for better lives, www.oecd.org www.slavonija.hr

Zakon o regionalnom razvoju (NN 153/09) 